\title{
A Model for a Virtual Fashion Museum
}

\author{
Mário Matos Ribeiro* \\ CIAUD, Faculdade de Arquitetura da Universidade de Lisboa, Portugal
}

Received Date: December 13, 2017; Published Date: January 22, 2018

*Corresponding author: Mário Matos Ribeiro, CIAUD, Faculdade de Arquitetura da Universidade de Lisboa, Portugal, Email: mmrdesigner@gmail.com

Abstract

The matrix of the $21^{\text {st }}$ century, characterized by a new reality resultant of the new technological and sociocultural context, seems to impose the design of new communication tools by reviewing today's museum models based on a deep reflection on the contemporary museum studies. After this immersion in research, we believe having achieved the design of a more innovative virtual fashion museum.

Keywords: Fashion; Museum; Virtual; Communication

\section{Introduction}

We have tried to look at the fashion curating discipline under a new cultural paradigm, i.e., as an open, transversal and endless practice, in order to design a multicultural conceptual board crossing diverse areas such as art, technology, design, culture and society, for which we defined the main objectives of this research as:

o To make a conceptual revaluation of the past and present time so as to design multidisciplinary creative atmospheres, to test innovative exhibition models adjusted to the Digital Era besides attempting to contribute for the dissemination of knowledge and culture;

o To contribute for a higher relevance of fashion and costume as anthropological and sociological tools, working on a global context;

o To reinforce the obvious need of using the internet in the museum context;

o To understand the new systems of cultural communication as well as the new individual and social values, using them as a starting point of the design of an effective platform to communicate fashion.

\section{Fashion and the Museum}

\section{PRE 1970}

Although fashion has been overlooked as a research subject in theoretical studies for several decades of the $20^{\text {th }}$ century as well as having been relegated to the field of history, during the second half of the previous century important academic and theoretical studies in the socio-cultural fields started to consider fashion as a subject of research and to see it under different approaches and perspectives, which reinforced its importance not only as a phenomenon but also as an important tool to analyze individual and social behaviors as a reflection of sociopolitical, economic and cultural changes.

On the other hand, the evolution of the Visual Culture studies-the interaction between Art and Society - would necessarily connect cultural studies, art history, critical theory and other fields connected with the social sciences, enlarging its focus to the new cultural products of a renewed urban landscape contaminated by visual images (from photography to advertising, from fashion to cartoons, movies, cosmetics, design, etc.).

Culture, today, is related to 'meaning practices' that allow examining the society trough the artifacts, with which the museum is deeply involved.

"Museums are deeply involved in constructing knowledge in this way through those objects, narratives, and histories that they bring to visibility or keep hidden" [1].

It was also during the end of the $20^{\text {th }}$ century that fashion started to be showcased in museums beyond the historical and anthropological contexts and be regarded not merely as a consumption phenomenon but as providing cultural meanings - interpreting from the identification, evaluation and relation of the artifacts with culture through conceptual frames of beliefs and values.

The roots of the concept of contemporary fashion exhibition date from the 1940s through a major traveling exhibition - Le Théâtre le la Mode - that took place in Paris, in 1945, immediately after the ceasefire. This interdisciplinary platform was organized by the Chambre Syndicale de la Couture Française, aiming to reaffirm the sophistication of French culture and regain clientele for the haute couture fashion houses - an important business sector before the World War II - in the new economic scenario 
and the distribution of money wealth. This important exhibition opened ceremoniously at the Pavillon Marsais, Musée des Arts Décoratifs, winning about 100000 visitors and later traveled through the most important capitals - from the European cities of London, Barcelona, Stockholm, Copenhagen and Vienna before heading to New York, Washington and S. Francisco.

The exhibition gathered around it the 'crème de la crème' of the Parisian cultural intelligentsia, sharing the stage of an imaginary theatre with small-scale sets designed by famous artists and inhabited by miniature dummies (in a 50|100 scale) wearing the most luxurious dresses by prestigious Parisian couture houses. Curiously the exhibition was designed by a group of famous artists and metteurs-en-artists while in exile, including Christian Bérard (director), Jean Cocteau, Boris Kochno, Eliane Bonabel, Jean Saint-Martin and André Beaurepaire, among others, with the objective of raising money for the reconstruction of the Nazi devastated France. The exhibition not only achieved its goal and raised millions of dollars to help the French economy but was also the rudimentary stage of an innovative form of exhibiting through context.

During the following decades Fashion as a creative discipline would always be associated with large blockbusters, especially the ones with the main goal of economic recovery or small exhibitions exclusively directed to the costume experts and historians.

\section{POST-1970}

The democratization of fashion in the sixties - the transformation from exclusive and luxurious couture garments for the elite into a clothes culture accessible to the masses - led the museums to adjust the perspective [2].

Until de beginning of the 1970s garments were ignored as an exhibition subject per se and were preserved in a very orthodox way, being exhibited almost exclusively on 'costume museums' in a very discreet way, utterly conservative and historically correct, protected from the viewers' gaze through the massive window displays or simply supporting other historical subjects. Thus, the curator's role was restricted to the physical preservation of the collections rigorously inventoried and exhibited in second-class galleries.

It was during the 1970s that Fashion Curating emerged as a discipline, via the relationships that important museums established with exceptional fashion and image experts - such as the legendary Diana Vreeland, a former fashion editor of Harper's Bazaar and American Vogue, who started a collaboration with the Metropolitan Museum of Art-The Costume Institute, NY, and the cosmopolitan fashion photographer and costume designer Sir Cecil Beaton, who organized the memorable exhibition 'Fashion: An Anthology by Cecil Beaton' at the Victoria \& Albert Museum, London.

If, for his exhibition, Beaton joined together an extraordinary and exquisite collection using his personal relationships with
European royalty, international socialites, French couturiers and beautiful people - which was later donated to the V\&A -, reinforcing its already important collection, presenting for the first time, all the garments contextualized through a contemporary vision, Vreeland went further.

Diana Vreeland curated a series of eleven exhibitions for The Costume Museum at The MET and the retrospective The World of Balenciaga (1972) was repeatedly attacked by her dissidents as having the gall to emulate the hallowed halls of the Art world [3] but widely acclaimed by its audience at the same time. "The World of Balenciaga introduced a brand new approach to costume exhibitions. In a spectacular setting, a fashion designer for the first time was given the focus reserved in museums for great artists" [4].

In 1973 Ruth Berenson reviewed Vreeland's Balenciaga exhibition in the New York Review, remarking that the show "accomplished the not inconsiderable feat of bridging the gap between art and fashion". Berenson remarks on the general prevailing tendency of the art world to dismiss the creativity of fashion and calls Balenciaga "the last great artist of fashion" [3].

Vreeland inaugurated a new concept of lighting, which came directly from her former editorial experience. Rejecting the most conventional lighting solutions, she turned the best angle or a beam of light into an object of study and used contextual artifices, such as the enormous baroque wigs in 'The Eighteen Century Woman' (1982-83) or the armors and stage props of the acclaimed Spanish singer Lola Montes for 'The World of Balenciaga' (1972).

"Her displays, which often included as many as one hundred mannequins, would appeal to the imagination and plunge the viewer into a milieu - perhaps a celebration of a great moment in Hollywood, or her versions of the eighteen century. She wanted the clothes to appear fashionable to the contemporary viewer. As she had done in her magazine pages, Diana Vreeland would give the viewer something more" [4].

Mrs. Vreeland ignored the rigorous recommendations of her conservative conservation staff and her representations were often incorrect historically, as stated by Eleanor Dwight: "Working with Vreeland was quite frustrating. While the staff members wanted the clothes to appear as they would have in the time period they represented, Vreeland wanted the clothes to look 'now' [5].

Contradicting the canons of that period, she promoted an intimacy between artifacts and viewers in a time when curators detested the idea of having the public to close to the exhibited pieces. Vreeland frees the clothes from the massive window displays and instead exhibits them on wood platforms covered with colored fabrics or mirrors so as to create a distance and reinforce theatricality.

Diana Vreeland extended her avant-garde editorial point of view to the museum context and changed this field "with 
an uncanny sense of style and drama" [5]. She imprinted her personal and non-expert touch by experimenting exhibition contexts that were theatrically dramatized, redefining a new lexicon of sensorial stimulation which went far from the visual sense, introducing soundtracks along with provocative color palettes, using strong scents, subverting the exhibit supports as well as the mannequins.

Diana Vreeland inaugurated a new concept of lighting, which came directly from her former editorial experience. Rejecting the most conventional lighting solutions, she turned the best angle or a beam of light into an object of study and used contextual artifices, such as the enormous baroque wigs in 'The Eighteen Century Woman' (1982-83) or the armours and stage props of the acclaimed Spanish singer Lola Montes for 'The World of Balenciaga» (1972). Her displays, which often included as many as one hundred mannequins, would appeal to the imagination and plunge the viewer into a milieu - perhaps a celebration of a great moment in Hollywood, or her versions of the eighteen century. She wanted the clothes to appear fashionable to the contemporary viewer. As she had done in her magazine pages, Diana Vreeland would give the viewer something more" [5].

Both collaborations achieved not only enormous popularity and increased the range of visitors but has also contributed to a further review of the fashion exhibitions, clarifying the relations trough Curating | Exhibition Making and Fashion Curator | Fashion Editor.

\section{The new museum formats}

The discussion on curating dates back from the 2001 symposium Curating Now: Imaginative Practice/Public Responsibility, organized by the American organization Philadelphia Exhibitions Initiative, as stated by the Cultural Program Director of the Pew Charitable Trusts, Marian A. Godfrey: "Curating Now has set a standard of critical dialogue that will challenge the other disciplines to create similar opportunities for artistic discourse that reaches both the Philadelphia region and beyond it" [6].

From this time on museums have been exploring different methodologies and contents, searching to frame themselves in the development of Technology and the Interactive Era.

"A new generation of museum professionals has attempted to reinvent the museum, to bring it to the twenty-first century as a place that can compete with other recreational venues for leisure time, a place more identified with providing opportunities for celebration than for contemplation. The thrust of today's museum is to 'attraction status', to be a 'destination', and to appeal to a mass audience. To achieve this, the direction of exhibition and education programs inevitably shy away from universal ideals and moves towards the familiar and commonplace. In the battle between high and low culture, low seems to have the upper hand" [7].

So it is possible to identify now innovative models and concepts, such as: a. The Virtual Museum (referred to in the next section).

b. The Object Museum, always related to extraordinary architecture masterworks, such as The Solomon Guggenheim Bilbao.

c. The 'Participatory Museum', focused on the study of the motivation, availability, and relevance of the 'participant' viewers, in order to interact with the community, a concept designed by the American curator Nina Simon that has been tested in museums around the world, such as the Santa Cruz Museum of Art \& History, the Dutch Museum of Natural History, the Copenhagen Museum or the Zuiderzee Open Air Museum.

d. The 'Project Museum' created around expressions of popular art and exploring the effects of the mass-media culture. Unorthodox, the 'Project Museum' is populist, experimental, fun, sensorial, immersive, being the 'The EMP' - Experience Museum (Seattle) its prime example.

e. The 'Museum on The Road', an itinerant museum format that crosses architecture with avant-garde artistic expressions, a concept launched by international fashion brands, such as Chanel with the 'Chanel Mobile Art' (Hong Kong, Seoul, Tokyo, NY and Paris, 2008-2010) and the Fondazione Prada with 'The Transformer' (Seoul, 20082009).

f. The 'Popup Museum', an ephemeral concept started by Fondazione Prada in 2012, January, through the initiative ' $24 \mathrm{~h}$ Museum', designed by the internationally acclaimed architect Rem Koolhass and the Italian artist Francesco Vezzoli in partnership, opened for only one day in Paris, during which the sets underwent the interactive metamorphosis that included lighting effects and vigorous DJ.sets of electronic music.

At the same time, the most recent studies known as 'New Museum Theory' - theories that question and revise the conceptual principles of Vergo's 'New Museology', even though they admit they are much related - identify four paradigmatic archetypes of the future museum:

a. 'The Sanctuary', as a result of the most traditional way to see the museum as a sacred contemplation space.

b. 'The Market Directed', focused on business plans more devoted to tourism than to the community, which tries to explore very popular contents, momentary blockbusters, tied to strong advertising campaigns and merchandising.

c. 'The Post Colonial Museum' that develops reconciliation discourse, redesigning the post-imperial representation to offer new approaches to the history and the cultural the identity of the colonial contexts.

d. And finally, the 'Post Museum', which has not yet very defined boundaries but already points to a dynamic cultural center, active, multidisciplinary, tolerant, multicultural and careful with minorities, characterized by calendars 
that include, together and/or intersected, different avantgarde cultural expressions such as art, photography, video art, fashion, publicity, world music, cinema, street-art, performing arts, discussions and controversies, etc.

\section{The museum in the digital era}

This research focused on the Virtual Museum due to today's cultural dynamic and effervescent context.

"It's cheap. It's fast. It offers great shopping, tempting food and a place to hang out. And visitors can even enjoy the art" announced the New York Times in one of 1997 issues [8] about the Virtual Museum.

As an important communication tool to produce culture and disseminate knowledge, the museum faces now the new paradigm of technology and interaction. Ignored for several years by the museum, the webspace started recently beginning an important strategic media, allowing the design of different contents for different viewers, giving global access to their digital archives, virtual galleries or even to virtual contents related to real ones through Immersive Virtual Reality.

As a matter of fact, in the end of last millennium, some of the most well-known museums started very carefully and timidly to use the Internet mainly as a database, rarely using it to support disciplines connected with fashion and design.

The existing model of Virtual Museum - in the real sense of the expression, with no physical space and based on Andre Malraux's Imaginary Museum - arose mainly as the preservation of cultural identity, and its prime examples are the Brazilian 'Museu da Pessoa' or the 'Virtual Museum of Canada' and recently the 'Century of The Child' by MOMA.

Its typology is defined by:

a. Big clusters around common subjects (the city, the region, the country);

b. A particular theme ('Museum of the Future', 'The Alternative Museum', 'Virtual Museum of Typography', among others);

c. The life and work of individuals (Virtual Museum of D. Quixote, Virtual Museum of André Malraux, etc.);

d. Scientific issues (e.g., Virtual Museum of Bacteria).

To our knowledge, no initiative focused directly on the fashion industry or design was issued until the end of 2011, with the exception of the largely acclaimed and reported 'Valentino Garavani Virtual Museum' by the Italian fashion house of Valentino.

The detailed analysis of this virtual museum allowed us to identify its stronger and weaker points, as defined by Paola Moscati [9]. "The Virtual Museum is not the real museum transposed to the web. The Virtual Museum is not an archive a database of, or electronic complement to the real museum. The virtual museum finally is not what is missing from the real museum [9]. A virtual museum must support an interdisciplinary approach, through the implementation of complex semantic associations, which will allow the user to understand the culture that is behind the objects and contextualize them." [10].

Quoting Silva (2012) - who states that The Valentino Museum does not provide a surprising experience - we can conclude that:

a. It is slow because visitors must download an app for every single access.

b. It is distant because the immersion is limited to static 2 and 3D spaces.

c. It is limited, because it is about one single designer, being thus as a mere database.

d. It is not comprehensive because its aim is the sole promotion of the label and the couturier.

e. It is closed and not interactive.

f. It is not registrable.

g. It is controlled and nondemocratic.

h. It is mainstream, not experimental.

\section{Conclusion: A new format of virtual museum}

The result of this research is a conceptual design within the virtual territory, which is a communication platform that optimizes the Internet's potential [11].

We believe to having achieved an original, unique and innovative model because its design was based on the real acceptation of the concept of the virtual museum since it is not associated with an existing entity or real content, on the contrary, it aims to establish cooperative networks, bridges among institutions and curators, artists and designers in order to interact with a large spectre of Internet browsers [12].

The final result was in line with the 'W3 Consortium' recommendations' principles, especially the Web for everyone; Web for everything; Knowledge Base e Trust and Confidence, as well as two important reports connected with the relationship between Museum and Technology, namely NMC: Horizon Report>2012, 2012 to 2015 Museum Editions (New Media Consortium | Marcus Institute for Digital Education in the Arts) and Museums and the Web 2011 (Pew Research Center), which present short, medium and long-term recommendations for the museum action [13].

We have also considered the main guidelines of immateriality curating particularly to the issues involving the responsibilities and control systems in collaborative work [14].

The basis of the model uses the following keywords:

i. Immersive

ii. Informal

iii. Interactive

iv. Personalized

v. Virtual 

vi. Creative
vii. Shared
viii. Provocative
ix. Experimental
x. Laboratorial
xi. Dynamic
xii. Global

The designed archetype aims to explore new maps, products and cultural practices using an interactive and dynamic grammar, supported by collaborative networks, which will be the source of exhibition subjects under different approaches, languages, and media, creating thus a space for a shared laboratory as well as the experimentation of ideas.

Although it is not our aim to define it's technological framework, for now, it seems obvious that it should use the 'Virtual Reality' and 'Augmented Virtual Reality' technology; we designed a navigation menu as the basis for further development [15].

Furthermore, it is very important to consolidate an extensive collaborative network that includes Kurators, Curators, Web and Animation Designers as well as digital artists, video- artists, movie directors, photographers, public relations, sponsors, artists, thinkers, and theorists, with the aim of optimizing each of the future exhibition contents.

We envision a design clearly inspired by the concept of MOTEL, in the sense in which is generally understood: "A hotel providing travelers with lodging and free parking facilities, typically a roadside hotel having rooms adjacent to an outside parking area or an urban hotel offering parking within the building" (dictionary.reference.com/), i.e., a very dynamic space that houses exhibition contents in alternation using a vast range of multidisciplinary languages and interacting approaches to communicate, and teach.

It seems of great importance to offer a mobile website, designed to mobile devices at the same time as a traditional website directed to visitors surfing from their desktops, although it will be mainly accessed by mobile devices.

Aside the main interactive fields, we aim to optimize the interaction with the viewers through a large range of applications (apps) that help to conceptualize and contextualize the exhibited objects and artifacts besides endowing exciting moments of discovery through various devices.

Special consideration will be given to social network practices to allow viewers to tag, comment and share videos, images and audio contents, thus reproducing its impact and dissemination. It is also important to clarify our intention to reach an extensive range of viewers, so that our mission of sharing and teaching is ensured.

Particular consideration will also be given to the continual development of technology connected with smart objects, also known as 'The Internet of Things - a convergence of multiple technologies ranging from wireless communication to the Internet and embedded systems and to Micro-ElectricalMechanical Systems (MEMS)-, as highly recommended by the NMC-Horizon Report: 2012 \& 2013 Museum Edition Reports.

Finally, we regard as very important to carry out the following strategic actions before launching publicly our MOTEL - Fashion Virtual Museum:
a. Validation of the concept
b. The search of a mobile operator for sponsoring
c. Consolidation of the network in all areas
d. Definition of technological supports
e. Design of navigation menus | web design | apps
f. Discussion of territories and conceptual frameworks by a closed board of curators
g. Design and edition of exhibition contents
h. Layout
i. Sponsoring and promotion

\section{References}

1. Hooper-Greenhill E (2006) Museums and the Interpretation of Visual Culture. Oxon, Routledge, UK.

2. Teunissen J (2014) Fashion and the Museums. In: Melchior M, Svensson B (Eds.), London: Bloomsbury, UK.

3. Stevenson N (2008) The Fashion Retrospective. Fashion Theory 12(2): 219-235.

4. Cumming V (2004) Understanding Fashion History. London: B. Batsford, UK.

5. Dwight E (2002) Diana Vreeland. New York: Harper Collins, UK.

6. Marincola P (Eds.) (2001) Curating Now: Imaginative practice/Public Responsibility. Philadelphia, USA: Philadelphia Exhibition Initiative.

7. Marstine J (Eds.) (2006) New Museum Theory and Practice: An Introduction. Oxford: Blackwell Publishing, UK.

8. Newhouse V (2006) Towards a New Museum. Monacelli Press, New York, USA.

9. Moscati P (Eds.) (2007) Virtual Museums and Archaeology: The Contribution of the Italian National Research Council. Firenze, Italy: Italian National Research Council.

10. Clark J (2014) Exhibiting Fashion: Before and After 1970. New Haven and London, Yale University Press, UK.

11. Melchior M (2014) Fashion and the Museums. In: Melchior M, Svensson B (Eds.), London: Bloomsbury, UK.

12. Mida I (2011) A Conversation with Harold Koda about Fashion and Art.

13. Postrel V (2007) Dress and Culture, in The Critics, May 2007. Washington: The Atlantic Media Group, USA.

14. Rothstein N (2010) 400 Years of Fashion. London, England: V\&A Publications, UK.

15. Silva F (2012) A Exposição como Objecto de Investigação/Experimentação: novas abordagens museográficas para comunicação de moda. Faculdade de Arquitectura da Universidade Técnica de Lisboa, Portugal. 

will reach you the below assets

- Quality Editorial service

- Swift Peer Review

- Reprints availability

- E-prints Service

- Manuscript Podcast for convenient understanding

- Global attainment for your research

- Manuscript accessibility in different formats

( Pdf, E-pub, Full Text, Audio)

- Unceasing customer service

Track the below URL for one-step submission https://juniperpublishers.com/online-submission.php 